\title{
The Failure of Lifestyle Environmentalism and the Promise of the Green New Deal for Working-Class People
}

\author{
Karen Bell, University of the West of England, Bristol \\ Gnisha Bevan, University of the West of England, Bristol
}

\begin{abstract}
There is an urgent need to address a range of environmental issues, including climate change, but the policies enacted to date have usually done nothing to address class inequities and have often led to increased working-class disadvantage. The causes of the climate and other environmental crises have often been located in problematic individual lifestyles, with little recognition of the time, economic and health constraints that make it difficult for working-class people to adopt green lifestyles. The Green New Deal (GND) presented an alternative policy paradigm that argued for environmental policies that, rather than increasing the pressure on disadvantaged groups, would have co-benefits for working-class people, low-income groups and communities of colour. However, the policy did not lead to electoral success for the political leaders that proposed it, in the United States (US) and the United Kingdom (UK), due to opposition representations of it as costly and threatening to working-class jobs. We interviewed 40 working-class people in the UK to find out how much they knew about the Green New Deal, what they thought about it as an environmental policy and how they felt about environmentalism, more generally. Our research indicates that there was a general lack of knowledge about GND, but great enthusiasm about it once explained, albeit with reservations about its implementation and limitations. The GND has huge potential to benefit the lives of working-class people but, we conclude, more, and better, outreach is needed for people to understand its potential to improve their lives.
\end{abstract}

\section{Key words}

Environmental justice, environmental inequity, policy justice, sustainability, climate change

\section{Introduction}

There is a growing literature on the social impacts and inequality outcomes of climate change mitigation policies and other environmental policies (e.g. Bell, 2021; Bell 2020; Hallegatte \& Rozenberg, 2017; Klinsky et al., 2016; Marcu \& Vangenechten, 2018; Petrini et al. 2017). It is apparent that the needs of working-class people have often not been considered when developing these policies (Bell, 2020) with harmful consequences for their health, incomes and wellbeing (Bell, 2020). Climate policies can have negative impacts on people in different structural positions. For example, policies that support solar energy and bio-fuels might have impacts on food justice through the conversion of agricultural land, reducing the amount of food that can be produced and, thereby, potentially increasing global food prices (Scott \& Smith, 2017). In the UK, subsidies for low-carbon technologies are often funded through increases in household electricity bills, disproportionally impacting on low-income groups (Oppenheim, 2016). Even the socially positive aspects of decarbonisation may not reach all 
social groups. For example, many green jobs have not been available to working-class people (Mason, 2009; Stevis, 2013).

The 2015 Paris Agreement established an unprecedented international accord to hold average global warming to well below $2{ }^{\circ} \mathrm{C}$ above pre-industrial levels and to pursue efforts to limit the temperature increase to $1.5^{\circ} \mathrm{C}$ (United Nations Framework Convention on Climate Change UNFCCC, 2015). To meet the Paris Agreement targets, global carbon dioxide (CO2) and other greenhouse gas (GHG) emissions need to be rapidly reduced and at least halved by 2050 (compared with 1990 levels) (IPCC, 2018). High Income Countries will need to do more, with reductions required of between $80 \%$ and $95 \%$ by 2050 . This means that climate policy, in particular, is going to impact on all of us and it is essential that it does not further harm those who are already living in relatively precarious and difficult situations, i.e. many working-class people.

Climate change mitigation policies, and other environmental policies, have various types of co-impacts, both positive (co-benefits) and negative (adverse side effects) (Markkanen \& Anger-Kraavi, 2019). Ideally, environmental policy would create many co-benefits and minimise the adverse impacts. Furthermore, to decarbonize effectively and rapidly, climate policies must avoid public resistance to transition policies. The introduction of increased fuel taxes and tolls as a climate mitigation strategy has already sparked social protests by workingclass people in a number of European countries, most notably the Gilets Jaunes in France (Bennett, 2018; Reid, 2018).

Therefore, environmental policies should be evaluated, not only for their efficacy in alleviating an environmental problem in a particular place, but also for their impact on inequality and whether they will reduce or worsen the inequities already faced by working-class people. While there is a huge potential to develop climate and other environmental policy that provides cobenefits for working-class people, prior environmental policies have often failed to do this (Bell, 2020). In general, they have tended to fail, and make life more difficult for, workingclass people. There are many examples of this 'policy injustice', including with regard to street cleaning services (Hastings 2007, 2009; Hastings et al. 2014; Bramley et al. 2012); pollution policy (Bell, 2020); energy policy (McCauley et al. 2013; Sovacool and Dworkin 2015; Jenkins 2018); waste policy (Bell 2020; Bell and Sweeting, 2013) and green jobs (Mason, 2009; Stevis, 2013), among other environmental policies. A first step in rectifying this injustice is to find out how working-class people view the policies on offer.

The UNFCCC (2019) has stated that, to meet the Paris Agreement targets, the needs, perspectives and ideas of all must be included in order to build solutions that are effective, just and sustainable. Yet, though citizen perspectives are considered to be important, their views on climate policy are still largely unheard by policy makers (Biddau et al., 2016) and this is particularly so in the case of working-class people and other disadvantaged social groups (Bell, 2021; Gay-Antaki, 2020; Phadke et al., 2015). Climate change responses have tended to be top-down, expert based and institutional (Copland, 2019; Kythreotis et al., 2019). Therefore, this research project asked working-class people what they think about the Green New Deal as an environmental policy and how this compared with some former policies, what we have termed here 'lifestyle environmentalism'.

\section{Lifestyle environmentalism and Green New Deal as opposing policy paradigms}


It has been noted that, over the past 40 years, environmental policy has often focused on the micro level (e.g. Jaeger, 2018; Johnston 2008; Maniates 2001; Szasz 2007). Individuals have been encouraged to modify their lifestyle and habits, while policies targeting environmental degradation at the point of production have been relatively few and far between. This has been described as the 'individualization' of environmentalism. Some suggest that this individualization has occurred in the interests of capital, with individual consumers, rather than producers, pinpointed as the source of environmental degradation and targeted as a focus for policy. Over time, we have seen that:

...scrutinizing industrial emissions gave way to enjoining individuals to measure and reduce their 'carbon footprints;' in place of restricting chemical inputs to agriculture, we gained the option to buy organic and local; rather than reduce postconsumer waste at its source, that waste was commodified, and we were volunteered to sort it (Jaeger, 2018, p. 396).

In contrast, the Green New Deal is a policy paradigm that locates the solutions to environmental degradation in governmental policy and investment. The 'Green New Deal' as a concept is highly contested but all versions centre on the idea of a government-led, society-wide effort to reduce greenhouse gas emissions and shift rapidly to a less carbon intensive economy (Chatsky, 2020). The name, Green New Deal, refers back to the New Deal, a set of policies and projects initiated in the United States by President Franklin D. Roosevelt in response to the Great Depression.

A number of recent texts have been published on why we need a Green New Deal and what it could look like (e.g. Aronoff et al., 2019; Klein, 2019; Pettifor, 2019). Since 2007, there have been campaigns for a Green New Deal around the world, including the Sunrise Movement in the United States, the pact for a Green New Deal in Canada, the Green New Deal for Europe initiative; policy on a Green New Deal from the Green Party of England and Wales; and the campaign for Labour for a Green New Deal in the UK Labour Party. For example, the UK Green New Deal plan has been described as '....an economic cure for the triple crisis of inequality, climate breakdown and failed finance' (Elliott et al., 2019, p. 3). The Decarbonisation and Economic Strategy Bill (2019) was introduced to the UK parliament prior to the 2019 general election. Set down by Caroline Lucas MP and Clive Lewis MP, it was, in effect, the Green New Deal Bill. The targets were to '...reduce emissions, restore nature, reduce inequality and increase well-being' (Elliot et al., 2019, p.9).

In March 2019, Labour Party members launched 'Labour for a Green New Deal' as a grassroots campaign. Their aim was to get the party to adopt a radical Green New Deal as policy. It proposed a region-specific green jobs guarantee, an expansion of public ownership, democratic control of industry, and mass investment in public transport and other infrastructure (Taylor, 2019). A commitment to a Green New Deal was then passed at the Labour Party annual conference in September. This included setting a target to decarbonise by 2030 which was not then government policy (Harvey, 20190; Blakely, 2019).

The GND idea was also supported by a number of leading Democratic candidates for the 2020 presidential election in the United States (Cawthorne, 2019). In the United States Congress, there have been a pair of resolutions, House Resolution 109 and S. Res. 59, sponsored by Rep. Alexandria Ocasio-Cortez (D-NY) and Sen. Ed Markey (D-MA) (e.g. Ocasio-Cortez 2019). The resolutions presented to the US Congress do not specifically mention taxes, fossil fuel subsidies or changes to economic growth strategies, but do indicate a limited degree of nature- 
based solutions through changes to agricultural practices (Congress Bill H.Res.109, 2019). Ocasio-Cortez has advocated $70 \%$ taxes on the wealthy to fund these investments (Choi, 2019). There has been consistently high support among Democrats for the proposal with Republicans generally tending to oppose (Gustafson et al. 2019). Biden's Climate Plan has incorporated some of the ideas of the GND, including funding for climate jobs, and considerations of equity and environmental justice (Weeden, 2021).

From 2008, the United Nations Environment Programme (UNEP) and other departments of the UN have also put forward a Global Green New Deal to create jobs in green industries (e.g. Barbier, 2009; UNDESA, 2009). In September, 2019, the United Nations Conference on Trade and Development (UNCTAD) produced a report on Financing the Green New Deal (UNCTAD, 2019). It recommended granting debt relief and restructuring debt repayment in order to allow developing countries to pay for green policies.

In April 2020, the European Parliament called for inclusion of the European Green Deal in the recovery programme from the Covid-19 pandemic (European Parliament, 2020). This programme has been critiqued for inadequate and inappropriate financing (e.g. Gabor, 2020). An alternative proposal, the Green New Deal for Europe, includes a commitment to '... redress Europe's colonial past, providing reparations to communities that suffer from centuries of European pollution and ensuring that we do not outsource extraction to the global South' (Green New Deal for Europe, 2020, np).

In terms of public support for the GND, a You Gov Blue poll of US voters in March 2019 found that 59 percent supported it (Data for Progress, 2019). However, another poll by The Washington Post and the Kaiser Family Foundation (KFF) (2019) found that 3 out of 4 United States citizens had heard little or nothing about the GND. Those who were most familiar with the plan were more likely to oppose it, with 6 out of 10 of those who had heard 'a good amount', opposing it. Among all adults, just 20 percent supported it and few wanted to be taxed to pay for it. Some of the negative views may have been influenced by former President Trump's negative discourse about GND and its potential cost (see, e.g., Friedman, 2019). There has not been similar polling in the UK, but the Labour Party's own survey found that, prior to the last election, at least two thirds of voters in their heartland marginal seats wanted radical government action on climate change (Labour Party, 2019). A number of UK campaign groups have more recently demanded that the government put protecting the environment at the heart of any post-Covid-19 economic stimulus package (BBC, 2021).

The Green New Deal has stimulated debate and contention with regard to the multiple interpretations and their differing underpinning values. There are controversies over different versions, especially in relation to the elimination of nuclear power, $100 \%$ renewable energy, and a jobs guarantee. Aronoff et al. (2019) for example, advocate a jobs guarantee because, as they point out, such jobs would be low carbon, socially useful work and there is no shortage of this kind of work to be done. Many people now do voluntary work with youth groups, in older people's homes, at food banks so, as they say 'we don't need to make work - we need to pay for it' (p.74). At the moment, this work cannot be done profitably and so, they argue, 'Eventually, doing meaningful, socially useful work will require a break with capitalism' (p.74). By contrast, Edward Barbier, who developed the 'Global Green New Deal' proposal for the United Nations Environment Programme in 2009, opposes a large-scale government jobs programme on the grounds that the government would be doing what the private sector and industry should be doing. He, instead, advocates carbon pricing, such as a carbon tax or 
cap-and-trade system, to encourage private sector innovation and investments in clean energy (Lavelle, 2019).

From the right, GND is criticised for its cost implications and attaching other issues to it that are not seen to be relevant to climate change (Chatzky, 2020). Critiques from the left argue that the GND is no more than 'greenwashing' as it fails to tackle the real cause of the climate emergency - limitless growth and over consumption, driven by capitalism (e.g. Dyne and Grey, 2019). It has also been critiqued from the left in terms of particular versions lacking a commitment to real change, with minimal genuine financial commitments (e.g. the critique of the European Green Deal by Gabor, 2020; Varoufakis and Adler, 2020). It is argued that reforms within capitalism will be ineffective and an anti-capitalist position should be adopted which provides for levels of consumption based on social need (e.g. Graham, 2019).

There are particularly divisions around the question of 'economic growth'. The benefits of increased consumption are highlighted in the Green New Deal Group's original 2008 report:

Any (Green New Deal) public spending should be targeted so that domestic companies benefit, and then the wages generated create further spending on consumer goods and services... (Green New Deal Group, 2008: 27).

This is unpalatable to those who stress the that the environment has been undermined by incessant economic growth. The likelihood of 'green-growth' as an effective strategy to transition to sustainability has been seriously questioned in a number of previous studies (e.g. Parrique et al., 2019; Sandberg et al., 2019; Hickel. and Kallis, 2020). However, degrowth can be politically difficult and Global South countries usually continue to look to economic growth as a mechanism for sustainable development (Stafford et al., 2020). The UK proposal for a GND (Elliott et al., 2019), the Green New Deal for Europe (2019) and the concepts of Doughnut Economics (Raworth, 2017) allow scope for particular types of economic growth without it being a key policy objective. Some are 'agnostic about economic growth' as advocated in the concept of 'doughnut economics' (Raworth, 2017), which aims to protect the environment and meet the needs of the worst off.

It has also been alleged that the GND, as proposed by the US Democrats and UK Labour Party, is '.. a new form of colonialism' (Rehman, 2019, np.). It is argued, 'Britain is planning to go green through a new phase of resource and wealth extraction of countries in the global south' (Rehman, 2019, np.). Rehman states that this 'green colonialism' will continue to be organised around entrenched economic interests, who have already done so much damage to people and the environment in the pursuit of profit. They will just shift their focus from oil, gas and coal to the extraction of lithium, cobalt and nickel from the Global South.

Similarly, Kolinjivadi (2019, np) argues for a decolonial GND that should '... prioritise restructuring global trade relations and reversing the enormous imbalances of cultural, economic and political power between Western governments and the global South... As part of this transformation, it should also make provisions for reparations for colonial injustices'. In the same vein, Aronoff et al. (2019, p.18) argue that 'An effective Green New Deal is also a radical Green New Deal' (emphasis in the original). They advocate for 'millions of people' to be 'organizing, striking and marching, shaping politics and the economy from below' to achieve this. They critique the 'faux Green New Deal' (i.e. not the radical programme necessary) for using tax incentives and prices signals focussed solely on clean energy, where a radical GND would use public investment and also address other environmental and social 
issues. The faux GND '...posits microeconomics as the solution to the climate crisis when what we really need is a new political economy' (p. 24).

A radical GND, therefore, has the potential to improve working-class lives in the High-Income Countries of the Global North, as well as the Global South. The research project engaged working-class interviewees in conversations about this possibility, gaining new insights into the potential and path to develop co-benefits from environmental policy.

\section{Methodology}

In this study we have used 'working-class' in the 'gradational' sense of the term, that is, linked to stratification based on people's occupations, educational qualifications, social status and power. Our operationalisation of the term, therefore, considers wealth and income, but also 'recognition', status, valuing and intergenerational aspects. The intergeneration aspects are considered important because employment and income in the UK are still very much determined by that of our parents (Social Mobility Commission 2017) (for more discussion on this, see Bell, 2020, chapter 2). The methodology combined a literature review (stage 1), followed by interviews (stage 2). For stage 1, a narrative literature review was chosen to provide the level of interpretation and critique necessary to deepen understanding (Greenhaulgh et al., 2018). It included analysis of papers in an iterative manner, drawing also on the authors' previous work in this area. Sources included databases (citation indexes, general searches, and subject specific searches), reference lists, library searches, grey literature and internet search engines (Google, Google Scholar). Both natural language and controlled vocabulary were used to detect material from formal and informal sources. As well as providing context, the literature review informed the interview questions and the analysis of the interview data.

In stage 2, we undertook 40 semi-structured interviews, of approximately 30-60 minutes duration, using informant-directed techniques (Peterson et al.,1994). The time period during which we carried out this stage was from July to October 2020, during the Covid-19 related lockdown. Therefore, we conducted the interviews over the phone or via the internet, as the participant preferred. The questions were in relation to knowledge and experience of the GND, if any; thoughts on environmentalism generally; and attitudes towards GND and lifestyle environmental policy initiatives.

All the interviewees were working-class according to at least one definition and brought up in working-class homes in non-professional families who had had no further education. Sixteen of the interviewees identified as Black, Asian and Minority Ethnic (BAME) ${ }^{1}$; twenty as female; ten were members of environmental organisations; twelve had been to university; and their ages were more or less evenly spread across a range from 20 to 80 . They were based in cities (15), towns (15) and rural areas (10) across England and Wales. They have all been given pseudonyms here to protect their identities. We used the following non-probability sampling strategies to select the interviewees: 'purposive sampling' (Patton, 1990; Mason, 2002), using participants who had particularly relevant knowledge and experience; 'snowball sampling' (Gilbert, 2001), using networks to gain access to information-rich participants; 'opportunistic sampling' (Miles \& Huberman, 1994), making the most of opportunities to meld the sample around the unfolding context; and 'maximum variation sampling' (Miles \& Huberman, 1994),

\footnotetext{
${ }^{1}$ The term, Black Asian and Minority Ethnic (BAME) is used here, in line with most UK policy language, though we acknowledge and accept the limitations of this (see, e.g. Okolosie et al., 2015).
} 
selecting participants who had the maximum diversity of experiences. The participants were identified via community, employment and educational networks and approached individually by email or phone. They were selected according to whether they contributed to diversity in the sample in terms of age, disability, location, ethnicity, gender and engagement (or not) in environmentalism. Although qualitative research does not require a large sample because the aim is not to make statements about prevalence and incidence against a target population, we aimed to interview as many people as possible in order to access a range of experience and knowledge. We continued until we reached 'saturation' in terms of a sufficient appreciation of patterns and themes.

We used the technique of 'framework analysis' to analyse the data, as described by Ritchie and Lewis (2003). The process involved a number of distinct, though interconnected, stages: familiarisation with the data, identifying themes, indexing, charting and interpreting. We used a cross-sectional 'code and retrieve' (Mason, 2002) method to organise the data into the themes. We also used Krueger and Casey's (2000) seven established criteria for interpreting coded data, considering: the meaning of words; the context in which words are used; internal consistency; frequency and extensiveness of comments; specificity of comments; intensity of comments; and big ideas (how the data relates to the bigger picture). The interview quotes below have been selected to illustrate key points. Ellipses have been used in their presentation to remove material that was not relevant to the topic being discussed. The meaning of the comment, taken in its context, has been retained.

In the research design, conduct and analysis, we also drew on our own experience as workingclass (first author) and mixed-class BAME (second author) environmentalists with, between us, decades of prior involvement and activism with environmental social movements.

Throughout the research and analysis, we have taken an 'intersectional' (Crenshaw, 1989) approach, rejecting essentialist perspectives in which all members of a particular social group, here working-class people are assumed to share a common, intrinsic set of characteristics or beliefs reflective of that group. The project recognises diversities that exist among workingclass people.

\section{Interviews}

A common theme among our interviewees was that they were not convinced by environmental and climate policies which put the responsibility for change on themselves. They expressed concerns about how environmentalism often put pressure on them personally without addressing the responsibility of corporations. For example, Shanti said:

I mean, even every day, we're micro managing our recycling, and yet..., I mean, the rubbish doesn't necessarily get recycled - it's just dumped somewhere... and we're trying to micro manage our homes by reducing, the type of, you know, plastics that are used and so forth. But you can't get away from it. Cos, you know, this government is still allowing the production of those types of plastics that can't be recycled, and are causing more damage. (Shanti interview, 27/07/20)

A number of the research participants expressed a frustration with the expectation that they were meant to spend their time, energy and finances on meeting the demands of environmental policy - recycling, buying green products, waiting for unreliable buses, paying carbon taxes etc. As other studies have highlighted (e.g. Bell, 2020; Bell, 2021), these additional burdens to 
their, already limited time, income and health, were not welcomed and could alienate them from environmental policy.

We - I say we, I can't speak for all of Wigan, but we're focused on working to pay our bills sort of thing... [the environment] ...falls down your list, the more you struggle, doesn't it really? If you're aware of it, you might agree with it but you've got bigger fish to fry in your own life maybe. I'll speak for myself, we're not uncomfortable, but we live hand to mouth with no cushion sort of thing. (Luke interview, 21/08/20)

Bristol has currently got a clean air plan that they're proposing which will limit diesel vehicles, will put high charges on coaches and delivery trucks, which will then be obviously passed straight on to the consumer. So it's still business as usual, it's just everybody's costs go up and people won't be able to travel and go about their daily business as much. (Paul interview, 17/07/20)

I think it needs to now be coming from the government and the businesses and the companies that are producing all of this plastic... It needs to be coming from them now because, me as a consumer, it's much cheaper to go to Tesco and buy, say, a bag of pasta that's wrapped in plastic than it is to go to one of these shops that obviously do zero waste, bring your own thing. It ends up costing more to do that. (Jade interview, $27 / 08 / 20)$

The participants found the discourses attached to these lifestyle policies did not resonate with them. They felt excluded and threatened by this emphasis, as they describe here:

Well, I mean, this view is shared by a number of people into green politics and stuff ... that there's too many people on the planet, especially in the third world, who are taking up too many resources. And it's not too far of a hop skip and a jump from that to advocating um, eugenics. (Dennis interview, 04/09/20)

I'm quite new to climate activism...I genuinely didn't want to get involved simply because ...it is very white, very middle class and everyone's vegan, everyone buys organic and it's just like, who can afford that? I couldn't do any of that stuff. (Kate interview, 02/09/20)

Some of the participants also mentioned that the environmental policy that was being rolled out often depended on exploitation and were constrained by the profit system. They seemed to understand the situation in a much more politically defined way than the lifestyle policies were attuned to.

And a lot of the things they're advocating, quite frankly, are leading to superexploitations in other parts of the world. It's not that the solutions aren't there, the solutions have been there for decades, .... the question is, does, does capitalism, does the profit system wish to pick those things up? And the answer to that is, unless there's sufficient return, the answer to that is no. (Dave interview, 02/08/20)

...those big companies, because we know, that they lobby strongly, whether governments here, or in the US, they lobby strongly....If those policies do not......maximise profit for themselves, then they do not, they are not pro... mostly it's 
about profit profit. profit, and those people who are thinking about profit, it's today not tomorrow. So that's where the difficulty is. (Hama interview, 09/08/20)

The research suggested, then, that these working-class interviewees rejected lifestyle environmental policy but would embrace a more radical alternative. However, many of the participants had received little information about the Green New Deal. Some had not heard of it at all. The interviewees who had been involved in promoting the GND in the UK confirmed that most of the people they spoke to about it (in 2019) had not heard of the policy. For example, Amaya mentioned that, while campaigning in the national elections:

Like, when we spoke to people, ... you know, 'what concerns you?', I couldn't get over how few people had even heard of the idea of a Green New Deal, never mind talking about policies on climate change. (Amaya interview, 30/10/2020)

When explained to them, the interviewees in our study mainly responded positively to the idea. Those that had heard of it, had come across it mainly via the election campaigns in the United States and the United Kingdom. We were told, for example:

Was that [the policy of] Jeremy Corbyn at the last election? It was about creating an economy around green energy and things, solar and stuff like that if I remember correctly? Yes, it was Bernie, the Green New Deal as well?... It just makes perfect sense. (Luke interview, 21/08/20)

Well, I know about it from American politics as I understand it. It's translated over here more recently. I could be wrong but I heard about it first in the context of America with Alexandria Ocasio-Cortez and some of the other younger Democrats proposing this as a way to increase and create jobs and economic prosperity in a more sustainable way. ...I do think it's a good idea. I think it's really important. (Liz interview, 21/08/20)

These working-class interviewees perceived that the GND offered many benefits in terms of jobs, better transport, better home insulation, and increased wellbeing. For example, one interviewee said on the topic of public investment in public transport and jobs:

In East Anglia, ... you can't exist where I live without a car. It just doesn't happen. You can't get anywhere for employment... if you live in one of the villages and you don't drive, you're not working. I don't know why that wouldn't be a good idea to try and create jobs for people whilst at the same time working towards something that's environmentally sustainable. (Liz interview, 21/08/20)

They particularly liked the way this policy paradigm moved the onus away from individuals and towards governments and companies; away from behaviour change and towards policy:

I think that's such an important shift in how we discuss the climate movement. Just by realising that responsibility lies with the leaders of this country, to make corporations and big businesses accountable for what they put out into the environment... And I think that's kind of been, in a way, why environmentalism hasn't been appealing to a lot of people because they feel almost as if they're being blamed and criticised. (Amaya interview, 30/10/2020) 
One of the interviewees that had been very involved in GND explained why she felt so enthusiastic about it and how she had been involved, as follows:

Finally, after decades of searching, we have a policy that talks about collective change, that talks about government and corporate responsibility and not about the individual. I think that's really, really important...My organizing around that was in working class communities and the industrialized towns and coastal areas where we went in and talked to ex-miners, workers from nuclear power plants, shop owners, schools. (Kate interview, 02/09/20)

Outreach is important for the GND, given the history of working-class exclusion from mainstream environmentalism in the US and UK (Bell, 2020; 2021). A strategy of meeting people where they are located seems to have worked, according to research participants who had been local GND organisers. For example, Kate explained that the GND meetings addressed people's everyday concerns, including about the transition to sustainability. She said:

We didn't go in and talk about climate policy. We went in to talk about what affects them in their communities today. ... One of the examples of that which I found really inspiring and really pushed me to do the work more was in Morecambe, where we had a round table event of over 200 people ... and we're able to say this is how many jobs it [the GND] would bring into Morecambe, this is how much money it would bring, this is how much it would reduce your family bills every year when we insulate council homes and how many jobs the insulation project would create. Then you could just see the energy and the passion in the room for communities wanting to come together and campaign for something that would make their lives better. (Kate interview, 02/09/20)

Those research participants who had been involved in promoting GND from below explained that though '....we did about 11 events all around the country and no one had heard of the Green New Deal' ...(Kate interview, 02/09/20), they managed to engage communities by inviting them to talk about jobs, local economy, changes to public transport and education, rather than the conventional green agenda. They also ensured that local people were respected as having expert knowledge by inviting local speakers and treating all the speakers equally. They explained the importance of listening to local people and what they wanted to do, rather than trying to persuade them what was needed. Kate, for example, said 'That, for me, is why the Green New Deal is so important and the organizing around the Green New Deal is so important, so we're not just looking at it as a policy drop. It's something that comes from people'. (Kate interview, 02/09/20)

However, as with the literature on this topic, our research participants did voice some potential concerns about the policy. One of the main drawbacks that the research participants were concerned about was the cost to themselves, either directly, through accessing the technology, or through increased taxes to pay for the green transition, as illustrated in Gabrielle's comment here:

It sounds like it should be a good idea. Yes, I'd go along with it. I guess the issue would be cost to the public and what they'd have to fork out to get all this new technology. ...because with the electric cars, you're also going to need to find the sockets to plug your car into... Yes, and of course, they'll have to cut the costs. Well, the cost of an electric car. (Gabrielle interview, 15/08/20) 
However, other participants felt it important to make this investment. When they heard that some people objected to GND because of the potential cost, they said:

You can't afford not to, can you? It's staring you in the face, isn't it? We'll end up doing this eventually but will we end up doing it too late, sort of thing... We're eternally in debt anyway, so what's a bit more debt to keep us from ending up under the water. (Luke interview, 21/08/20)

We should spend [public money] it on what instead? Public money, that's for the public for the longer term...[They should stop spending on] the military, maybe-- I don't know... I understand why, obviously, we need military, but it just seems like one of those things in the 21st century that you just put less money in. (Liz interview, 21/08/20)

Some of the interview participants were also concerned that the proposed benefits may not materialise for working-class people. For example, Tiara said:

What's a green job? Who would be doing it?... if there's gonna be something like that, and things available, it needs to be done in a way that people can access those jobs... And I just feel like it needs to be in a different way so that people who have never done that world of work are encouraged to do it... You know, they'll advertise an environmental job, I know most people wouldn't even try to apply. (interview Tiara, 07/09/20)

A few of the participants looked at the limitations of GND, seeing it as solely transitioning jobs, rather then as the wider desire to reduce inequality and increase wellbeing that is inherent in some versions. For example, Yasmin said:

I haven't paid it lots of attention. ... it doesn't excite me. That's not to say some of the key demands are...you know, 'let's invest more of our energy into our economy around green jobs', you know, 'let's transition the types of employment that people have'. I guess my wish for the world is a bit bigger than that ... I'm, like, 'how about we completely reframe our economy, and our relationship to work and our relationship to each other?'. So, I don't think it's a bad thing, but it hasn't excited or inspired me... I think I want more. (interview Yasmin, 28/08/20)

What participants particularly valued about GND, as opposed to other environmental policies, is that it seemed to have more of an ethos of global solidarity and equity alongside localism and respect for working-class people and other marginalised groups, as these comments illustrate:

The Green New Deal Policies, a lot of it does actually address how we can't just shift the burden onto, you know, far away countries... Because quite a lot of policies actually, when you look beneath the surface, a lot of sustainable policies just kind of shift the burden to another place. And, it's actually quite radical, for the Green New Deal to have kind of confronted that head on. (Amaya interview, 30/10/2020)

For people to be gainfully employed locally would actually allow them, because I think people when they're poor, they're, they actually don't give a stuff about green issues worrying about how they're going to eat. (interview Barbara, 12/08/20) 
I've met a lot of really empowering BAME women who have been at the heart of that [GND] movement, and who aren't just tokenised for a photo opportunity, but are literally like, they have a seat at the table and they're working hard to actively centre, to be centred, and for their ideas to be heard. Which, yeah, it was such a breath of fresh air... That's why I'm part of it I guess. (Amaya interview, 30/10/2020)

Overall, then, the working-class interviewees were positive about the possibilities of a Green New Deal, although with some cautiousness about what it might mean, in stark contrast to their views on lifestyle environmentalism which they found annoying and off-putting.

\section{Conclusion}

This study endorses the literature which indicates that lifestyle environmentalism does not enthuse or inspire working-class people and has often made their lives more difficult. It also supports the literature in terms of indicating that knowledge and understanding of GND is minimal among working-class people. Similar reservations to those of academics were also voiced in relation to GND, in terms of 'I want more'. However, depending on the version of the GND, these working-class people were broadly supportive. Proponents of the GND did not, however, lead to election triumphs in terms of the candidature for the US elections and the UK general election, although in both cases, this may have had more to do with lack of internal party support for those candidates, rather than the views of the working-class public.

Environmental and climate policy has the potential to deliver enormous co-benefits in terms of equity, solidarity and anti-oppressive practice. The Green New Deal as presented by OcasioCortez and Saunders in the US and Corbyn, Lucas and McDonald in the UK, could be the policy paradigm that would deliver those benefits. The working-class people we interviewed found many positive aspects to this policy in terms of better services, more job opportunities, warmer homes, better public transport, challenging the harmful companies, international solidarity, and a bottom-up development model. However, they often knew little or nothing about the policy and the election messages on this topic had not reached them or they had been misinformed. Therefore, more needs to be done to build awareness about this policy paradigm and to involve working-class people in its development. Without including working-class people in the development and communication of this policy, there may be sub-optimal interventions that have lower impact, effectiveness, public support and value for money. Given the differential impacts of the Covid-19 pandemic across race, class and several other disadvantaged groups (IFS, 2020), it is also an important time to embed inclusive climate and environmental policy in Covid-19 recovery plans. The public have seen that it is important to spend public money in a crisis and so concerns expressed, pre-Covid, about costs may now be dwindling. Working-class people have borne the brunt of the pandemic and now is the time to rebuild a new sustainable economy that works for them.

\section{Author Bios}

Karen Bell - Formerly a youth and community development worker, for 15 years Karen worked alongside disadvantaged communities to address issues such as social inequality, racism, disability discrimination, and environmental exclusion and inequity. As an academic, her work has looked at how to achieve environmental justice in a variety of political, economic and cultural settings; how to build a fair and inclusive transition to sustainability; and how to build an environmental movement that is attractive to a wider range of social groups. From a 
working-class background, she is also author of Working-Class Environmentalism: An Agenda for a Just and Fair Transition to Sustainability (Palgrave, 2020).

Gnisha Bevan co- developed and co-leads the Black Seeds Environmental Justice Network which seeks to recognise and support environmentalists of colour. She was the UK Festival of Nature Community Manager 2021 and she works as a consultant advisor on a range of environmental and social justice projects. She is also currently studying for an MSc degree in Sustainable Development in Practice at the University of the West of England, Bristol. She is an education specialist and has worked on a number of international projects, including collaborating with the Rwandan Education Board, international development partners and the voluntary sector to improve the quality of education in Rwanda

\section{Bibliography}

Aronoff, K., Battistoni, D., Cohen, A. and Riofrancos, T. (2019). A planet to win-why we need a Green New Deal. Verso.

Barbier, E. (2009). A Global Green New Deal, Report prepared for the Green Economy Initiative of UNEP

https://sustainabledevelopment.un.org/index.php?page=view\&type $=400 \& n r=670 \& m e$ $\underline{\mathrm{nu}=1515}$

Bell, K. (2020). Working-class environmentalism. Palgrave.

Bell, K. (Ed.) (2021). Diversity and inclusion in environmentalism. Routledge.

Bell, K. and Sweeting, D. (2013). Urban waste collection: an environmental justice issue? In M.J. Zapata (Ed.), Waste in the city: pp. 201-223, Policy Press.

Blakeley, G. (2019, October 2). Why we need a Green New Deal to solve humanity's greatest challenge. New Statesman.

https://www.newstatesman.com/politics/economy/2019/10/why-we-need-green-newdeal-solve-humanity-s-greatest-challenge

Bramley, G., Bailey, N., Hastings, A., Watkins, D., and Croudace, R. (2012). Environmental justice in the city? Challenges for policy and resource allocation in keeping the streets clean. Environment and Planning A, 44(3), 741-761. https://doi.org/10.1068/a44409

Cawthorne, C. (2019, February 16). Ocasio-Cortez: 'Every Democratic presidential candidate' supports Green New Deal. Washington Free Beacon.

https://freebeacon.com/politics/ocasio-cortez-every-democratic-presidentialcandidate-supports-green-new-deal/

Chatzky, A. (2020). Envisioning a Green New Deal: a global comparison. Council on Foreign Relations, New York https://www.cfr.org/backgrounder/envisioning-green-new-dealglobal-comparison

Chappell. E. (2019, November 7). Labour climate policy backed up by new polling on 2030 target. LabourList. https://labourlist.org/2019/11/labour-climate-policy-backed-up-bynew-polling-on-2030-target/

Choi, M. (2019 January 4). Ocasio-Cortez floats 70 percent tax on the super wealthy to fund Green New Deal, Politico. https://www.politico.com/story/2019/01/04/ocasio-cortez70-percent-tax-1080874

Congress Bill H.Res.109 (2019) Recognizing the Duty of the Federal Government to Create a Green New Deal. 116th Congress (2019-2020)

Crenshaw, K. (1989) Demarginalising the intersection of race and sex: A black feminist critique of antidiscrimination doctrine, feminist theory and antiracist politics, University of Chicago Legal Forum, 1: 139-167

Data for Progress (2019) Memo: U.S. voters strongly support bold climate solutions 
https://www.filesforprogress.org/memos/GND-350-DFP-polling.pdf

Decarbonisation and Economic Strategy Bill (2019)

https://publications.parliament.uk/pa/bills/cbill/2017-2019/0365/190365.pdf

Dyne, B. and Grey, B. (2019, March 5). The fallacies and evasions of the Green New Deal.

World Socialist Website. https://www.wsws.org/en/articles/2019/03/05/deal-m05.html

Elliott, L., Hines, C., Leggett, J., Lucas, C., Murphy, R., Pettifor, A., Secrett, C., Simms, A. and Tily, G. (2019). The Green New Deal: a bill to make it happen. The Green New Deal Group, London, https://greennewdealgroup.org/wpcontent/uploads/2019/09/GND_A_Bill_To_Make_I t_Happen.pdf

European Parliament (2020, April 17). COVID-19: MEPs call for massive recovery package and Coronavirus Solidarity Fund. News European Parliament. https://www.europarl.europa.eu/news/en/press-room/20200415IPR77109/covid-19meps-call-for-massive-recovery-package-and-coronavirus-solidarity-fund

Extinction Rebellion (2020). Our Demands: Here's some more information about the possible solutions. https://extinctionrebellion.uk/the-truth/demands/

Friedman, L. (2019, Feb 21) What is the Green New Deal? A climate proposal, explained, The New York Times. https://www.nytimes.com/2019/02/21/climate/green-new-dealquestions-answers.html

Gabor, D. (2020, Feb 19) The European Green Deal will bypass the poor and go straight to the rich, The Guardian.

https://www.theguardian.com/commentisfree/2020/feb/19/european-green-dealpolish-miners

Graham, S. (2019, March 16). Green Capitalism': a critical review of the literature (Part III). RS21. https://www.rs21.org.uk/2019/03/16/revolutionary-reflections-greencapitalism-a-critical-review-of-the-literature-part-iii/

Green New Deal Group (2008, July 20). A Green New Deal: Joined-up policies to solve the triple crunch of the credit crisis, climate change and high oil prices. New Economics Foundation. https://neweconomics.org/2008/07/green-new-deal

Green New Deal for Europe (2020). The promises of the Green New Deal. DiEM25. https://www.gndforeurope.com/

Gustafson, A., Rosenthal, S.A., Ballew, M.T., Goldberg, M.H., Bergquist, P., Kotcher, J.E., Maibach, E.W. and Leiserowitz, A. (2019). The development of partisan polarization over the Green New Deal. Nature Climate Change. 9(12), 940-944.

Hallegatte, S. and Rozenberg, J. (2017). Climate change through a poverty lens. Nature Climate Change, 7, 250-256. https://doi.org/10.1038/s41558-019-0621-7

Harvey, F. (2019, September 24). Labour's climate policies: what are they and what do they mean?. The Guardian. https://www.theguardian.com/politics/2019/sep/24/laboursclimate-policies-what-are-they-and-what-do-they-mean

Hastings, A. (2007). Territorial justice and neighbourhood environmental services: a comparison of provision to deprived and better off neighbourhoods in the UK. Environment and Planning C-Government and Policy, 25(6), 896-917. https://doi.org/10.1068/c0657

Hastings, A. (2009). Poor neighbourhoods and poor services: evidence on the 'rationing' of environmental service provision to deprived neighbourhoods. Urban Studies. 46(13), 2907-2927. https://doi.org/10.1177/0042098009344995

Hastings, A., Bailey, N., Bramley, G., Croudace, R., and Watkins, D. (2014). 'Managing' the middle-classes: Urban managers, public services and the response to middle-class capture. Local Government Studies, 40(2), 203-223.

https://doi.org/10.1080/03003930.2013.815615 
Hickel. J. and Kallis, G. (2020) Is green growth possible?, New Political Economy, 25(4), 469486. https://doi.org/10.1080/13563467.2019.1598964

Jenkins, K. (2018). Setting energy justice apart from the crowd: Lessons from environmental and climate justice. Energy Research and Social Science. 39, 117-121.

https://doi.org/10.1016/j.erss.2017.11.015

Labour Party (2019, November 28). New polling reveals Labour's Green Industrial Revolution popular in northern labour heartlands.

https://www.labourgnd.uk/news/2019/11/28/new-polling-reveals-labours-greenindustrial-revolution-popular-in-northern-labour-heartlands

Lavelle, M. (2019, January 3). New Congress Members See Climate Solutions and Jobs in a Green New Deal. Inside Climate News.

https://insideclimatenews.org/news/03012019/green-new-deal-climate-solutions-jobs2018-year-review-ocasio-cortez-castor-sunrise-movement-congress/

Johnston, J. (2008). The citizen-consumer hybrid: Ideological tensions and the case of whole foods market. Theory and Society. 37(3), 229-70. https://doi.org/10.1007/s11186-0079058-5

Jaeger, A.B. (2018). Forging hegemony: How recycling became a popular but inadequate response to accumulating waste. Social Problems, 65(3), 395-415. https://doi.org/10.1093/socpro/spx001

Klein, N. (2019). On fire: The burning case for a Green New Deal. Allen Lane

Klinsky, S., Roberts, T., Huq, S., Okereke, C., Newell, P., Dauvergne, P., Bauer, S. (2016). Editorial: Why equity is fundamental in climate change policy research. Global Environmental Change, 44, 170-173. https://doi.org/10.1016/j.gloenvcha.2016.08.002

Kolinjivadi, V. (2019, December 7). Why a 'Green New Deal' must be decolonial, Al Jazeera. https://www.aljazeera.com/indepth/opinion/green-deal-decolonial191202134707310.html

Marcu, A. and Vangenechten, D. (2018). Managing a sustainable transition to a low-carbon society: The socio-economic impacts of mitigation policies. Geneva: International Centre for Trade and Sustainable Development (ICTSD).

Markkanen, S. and Anger-Kraavi, A. (2019). Social impacts of climate change mitigation policies and their implications for inequality, Climate Policy, 19(7), 827-844. https://doi.org/10.1080/14693062.2019.1596873

Mason, C.N. (2009). Race, gender and the recession. NYU Wagner.

McCauley, D.A., Heffron, R.J., Stephan, H., and Jenkins, K. (2013). Advancing energy justice: the triumvirate of tenets. International Energy Law Review, 32, 107-110.

Maniates, M.F. (2001). Individualization: Plant a tree, buy a bike, save the world? Global Environmental Politics 1(3), 31-52.

Okolosie , L. , Harker , J. , Green , L. and Dabiri , E. (2015, May 22). Is it time to ditch term 'black, Asian and minority ethnic' (BAME)?, The Guardian.

https://www.theguardian.com/commentisfree/2015/may/22/black-asian-minorityethnic-bame-bme-trevor-phillips-racial-minorities

Ocasio-Cortez, A. (2019, Feb 12). 'H.Res.109 - 116th Congress (2019-2020): Recognizing the duty of the Federal Government to create a Green New Deal'. https://ocasiocortez.house.gov/sites/ocasiocortez.house.gov/files/Resolution\%20on\%20a\%20Green $\% 20 \mathrm{New} \% 20 \mathrm{Deal} . \mathrm{pdf}$

Parrique, T., Barth, J., Briens, F., Kerschner, C., Kraus-Polk, A. Kuokkanen, A. and Spangenberg, J.H. (2019). Decoupling debunked: Evidence and arguments against green growth as a sole strategy for sustainability. European Environmental Bureau, Brussels. https://eeb.org/library/decoupling-debunked/

Petrini, M. A., Vieira Rocha, J. and Brown, C. (2017). Mismatches between mill-cultivated 
sugarcane and smallholding farming in Brazil: Environmental and socioeconomic impacts. Journal of Rural Studies, 50, 218-227.

https://doi.org/10.1016/j.jrurstud.2017.01.009

Pettifor, A. (2019). The case for the Green New Deal. Verso.

Raworth, K. (2017). Doughnut economics: Seven ways to think like a 21 st Century economist. Random House.

Rehman, A. (2019, May 4). The 'green new deal' supported by Ocasio-Cortez and Corbyn is just a new form of colonialism, The Independent.

https://www.independent.co.uk/voices/green-new-deal-alexandria-ocasio-cortezcorbyn-colonialism-climate-change-a8899876.html

Rowlatt, J. (2021, June 4) Demands grow for 'green industrial revolution'. $B B C$. https://www.bbc.co.uk/news/science-environment-52906551

Szasz, A. (2007). Shopping our way to safety. University of Minnesota Press.

Sandberg, M., Klockars, K. and Wilén, K. (2019). Green growth or degrowth? Assessing the normative justifications for environmental sustainability and economic growth through critical social theory. Journal of Cleaner Production, 206, 133-141. https://doi.org/10.1016/j.jclepro.2018.09.175

Social Mobility Commission. (2017, June 28) Social mobility policies between 1997 and 2017: time for change. GOV.UK. https://www.gov.uk/government/publications/socialmobility-policies-between-1997-and-2017-time-for-change

Sovacool, B.K., and Dworkin, M.H. (2015). Energy justice: conceptual insights and practical applications. Applied Energy, 142, 435-444. https://doi.org/10.1016/j.apenergy.2015.01.002

Stafford, R., Croker, A.R., Rivers, E.M., Cantarello, E., Costelloe, B., Ginige, T., Sokolnicki, J., Kang, K., Jones, P.J.S., McKinley,E. and Shiel, C. (2020). Evaluating optimal solutions to environmental breakdown. Environmental Science \& Policy, 112, 340-347. https://doi.org/10.1016/j.envsci.2020.07.008

Stevis, D. (2013). Green Jobs? Good Jobs? Just Jobs? USA Labour Unions Confront Climate Change. In N. Räthzel and D. Uzzell (eds.), Trade unions in the Green Economy: Working for the environment. Routledge.

Taylor, M. (2019, March 22). Labour members launch Green New Deal inspired by US activists. The Guardian. https://www.theguardian.com/politics/2019/mar/22/labourmembers-launch-green-new-deal-inspired-by-us-activists

UNCTAD (2019). Trade and Development Report 2019: Financing a global Green New Deal. United Nations Conference on Trade and Development. https://unctad.org/webflyer/trade-and-development-report-2019

UNDESA (2009). A Global Green New Deal for Climate, Energy, and Development, https://sustainabledevelopment.un.org/index.php?page=view \&type $=400 \& n r=46 \& m e n$ $\mathrm{u}=1515$

Varoufakis, Y. and Adler, D. (2020, February 7) The EU's green deal is a colossal exercise in greenwashing, The Guardian.

https://www.theguardian.com/commentisfree/2020/feb/07/eu-green-deal-greenwashursula-von-der-leyen-climate

Washington Post and Kaiser Family Foundation (2019) Climate Change survey https://www.washingtonpost.com/context/washington-post-kaiser-family-foundationclimate-change-survey-july-9-aug-5-2019/601ed8ff-a7c6-4839-b57e3f5eaa8ed09f/?tid=1k_inline_manual_8\&itid=lk_inline_manual_5

Weeden, M. (2021) How the Green New Deal Informed the Joe Biden Climate Plan, One Tree Planted, https://onetreeplanted.org/blogs/stories/biden-climate-changegreen-new-deal 
White, D. (2020). Just transitions/design for transitions: Preliminary notes on a design politics for a Green New Deal. Capitalism Nature Socialism, 31(2), 20-39.

https://doi.org/10.1080/10455752.2019.1583762 